\title{
COMMUNITY PARTICIPATION IN THE PLANNING OF LOCAL DESTINATION MANAGEMENT
}

\section{PARTICIPACIJA ZAJEDNICE U PLANIRANJU LOKALNOG DESTINACIJSKOG MENADŽMENTA}

\author{
Marko Koščak ${ }^{1}$, Tony O'Rourke ${ }^{2}$, Dinko Bilićs \\ Faculty of Tourism, University of Maribor, Slovenia ${ }^{1}$; Institute of Banking and Finance, London, United \\ Kingdom², Croatian Communation Association, Zagreb, Croatia ${ }^{3}$ \\ Fakultet za turizam, Sveučilište u Mariboru, Slovenija ${ }^{1}$; Institut za bankarstvo i financije, London, Ujedinjeno \\ kraljevstvo ${ }^{2}$; Hrvatsko komunikološko društvo, Zagreb, Hrvatska
}

\section{Abstract}

In this paper we suggest that modern tourism planning of a destination should include participation from all levels of the community (direct stakeholders, local residents and differing age groups) if the participatory process is to be extensive and universal within the community. We see participatory planning as a critical success factor in seeking to satisfy the requirements of the modern paradigm of sustainability and responsibility in tourism. A community-based approach to tourism development is a prerequisite to sustainability. This focuses on community involvement in the planning and development process, and developing the types of tourism, which generate real social and economic benefits to local communities. Representing the interests and fulfilling the needs of various users is one reason for enabling their participation. Interestingly, children \& youth are often overlooked in this regard even though adults may not adequately represent their needs. An important outcome of participatory planning is the process of collective learning that takes place through the underlying process of dialogue. We will refer in the paper to parallel research conducted with colleagues in Slovenia focusing in detail on the role of children \& youth in the participatory process of developing sustainable tourism at a local level. This includes a view that planning for sustainable tourism development is an effort to shape the future. Among

\section{Sažetak}

U ovom radu polazimo od pretpostavke, kako u suvremenom planiranju turističkog razvoja destinacije treba težiti da su u participativni proces uključene sve razine lokalne zajednice (direktni dionici u turizmu, lokalno stanovništvo kao i različite starosne skupine). Posljednje navedeno jedino osigurava univerzalni i sveobuhvatni participativni proces planiranja u turističkoj destinaciji. Ocjenjujemo, da je participativnost svih dionika kritičan faktor uspjeha za osiguranje održivog i odgovornog turističkog razvoja u destinaciji. Na taj način osiguran je razvoj turizma, koji generira realne socijalne, okolišne i ekonomske koristi za lokalnu zajednicu. Mogućnost za iskaz participacije treba biti omogućena svim dionicima u destinaciji. Interesantno, djeca i mladi često su izostavljeni iz ovog procesa, iako u većini slučajeva odrasla generacija ne može adekvatno izraziti njihov pogled na budući turistički razvoj u destinaciji. Značajan rezultat participativnog procesa je i međusobna komunikacija te izmjena iskustva u procesu planiranja razvoja turističke destinacije. U radu se referiramo i na paralelno istraživanje, koje su izveli kolege iz Slovenije, s fokusom na ulogu djece u participativnom procesu planiranja turističke destinacije. Smatramo da je to od važnog značaja za osiguranje elementa održivosti za budući razvoj u turističkoj destinaciji. Između svih dionika u planiranju razvoja destinacije, djeca i mlada generacija trebaju i moraju 
stakeholders and community participants, children \& youth have a significant voice in the future and to a strong degree should have the right to engage in development. The paper seeks to assess the role of participatory structures in planning and development and in the role of children \& youth as stakeholders in the planning of local destination management.

\section{Introduction}

Tourism affects a number of different aspects of the lives of young generation, in particular in tourist destinations in Slovenia. However, families living in tourist destinations in Slovenia, some of whom may work in the tourism industry and whose livelihoods depend on tourism, may not have direct involvement in the overall development or planning of these tourist destinations. Less seldom do children take part or are involved in these participative planning processes.

With a few exceptions, children are routinely excluded from the planning process in tourism destinations. Local tourism development and destination planning should be organised as kind of "creative way of tourism" which is a form of tourism that complies with culture and community ways. The community can and should manage their own tourism. Participatory planning is one of the most important elements and a key approach of the tourism development if one wishes to satisfy the requirements of the modern paradigm of sustainability and responsibility in tourism. Furthermore a community-based approach to tourism development with involvement of a broad number of local community stakeholders is a prerequisite to sustainability. This approach to tourism focuses on community involvement in the planning and development process, and developing the types of tourism, which generate benefits to local communities. It benefits local residents of differing age and sex and not those outside the community. Maximising benefits to local residents typically results in tourism being better accepted by them imati svoju ulogu i svoj glas, kako bi participativni proces bio cjelovit odnosno sveobuhvatan.

Ključne riječi: održivost, participationo planiranje, mlada generacija i djeca, lokalni destinacijski menadžment, etički turizam

and dynamises their active support in the conservation of local resources $/ \mathbf{1} /$.

In fact, very often children \& youth are not seen as real citizens with the right or voice to participate in shaping policies. Representing the interests and fulfilling the needs of various users is a key reason for enabling their participation. However, children are often overlooked in this regard given that adults cannot adequately represent their needs. Moreover, an important outcome of participatory planning is the process of collective learning that takes place through the dialogue. People learn about each other, their environment, and self-governance. The earlier they are engaged in this process, the better citizens they become. Planners, even those who are committed to meaningful participation of the public, often ignore the fact that children are part of the public and need to be reminded of the compelling reasons for involving children in local community decision-making. Involving children in the place-making function is especially important because tourism places (and active engagement with such places) performs an important role in the healthy development of children into well-adjusted adults and responsible citizens. Being rooted in a place, calling a place 'home', translates into caring for that place, not only for oneself but for generations to come.

Participation can only be guaranteed if decision-making processes are fully transparent. Logistic, technical, and financial support and means of communication should be made available to make the participation of all those affected possible. This applies especially to disadvantaged population groups. In order to ensure 
the comprehensive, prior-informed and active equal participation of all stakeholders in tourism, the flow of information, education and communication must be improved. The relevant authorities and the tourism industry in particular should support this process at international and local levels /2/.

Planning for sustainable tourism development is an effort to shape the future. Children \& youth, who clearly have the largest stake in the future, should therefore have the right to participate in planning that stake. Adult attitudes towards place reflect, immediately and largely, short term concerns and motivations; children's perceptions are free of adult concerns. In this regard, children \& youth are much more objective in their assessment of what matters. Furthermore, adults' perceptions and evaluations of place depend on the instrumental value of place; place is often a commodity, a resource to be exploited. For children \& youth, place is inherently valuable in itself; this is why favourite places are often those that are remembered from childhood and also why children ought to have a voice in the planning of tourism destination, to achieve a sustainable and responsible long term life $/ 3 /$.

Another important component of this paper relates to the role and sustainability of cultural/heritage tourism within the overall tourism product. In two of the areas (Brežice and Trebnje) chosen in the parallel research survey /4/ the major impact of tourism derives from the cultural/heritage and sustainable sector. This type and form of tourism activity tends to be developed in remoter or more peripheral regions and thus distinctive from those areas where Large-Scale Tourism (LST) is manifested. Group sizes will thus be either less than 20, or formed of independent travellers. In LST areas, tourism groups will tend to be above 20 and frequently related to a standard tour bus grouping of between 30-45 or compatible with charter flight groups of 80-120. Sustainable tourism has a lesser profile at both an economic and destination management level due in part to the size of the groups, but also in regard to the impact of that form of tourism on the socio-economic environment of the host towns. Sustainable tourism is less evident but undoubtedly has a highly significant profile in terms of income generation for those working in the environmental, heritage, cultural and agro-tourism sectors.

We should also make mention of the engagement of children \& youth in active tourism management. In farm or rural tourism - an important component of sustainable tourism young family members may well have a strong degree of engagement in the family business. They may have some after-school engagement in helping with accommodation servicing, food preparation or supporting another form of guest services. Whether these tasks are remunerated may not be clear, but in effect, these children will have a prominent role as stakeholders. This may be as successors in the family business or simply because the economic sustainability of the family tourism activity is of future economic benefit to them. In LST establishments, such a degree of engagement by young family members may be less direct and less engaged; it may simply relate to the potential for vacation jobs working in hotels or restaurants as temporary/casual employees. However, those children will not have the same degree of strategic engagement in the enterprise evident from those children working in cultural/heritage and sustainable tourism.

The failure to engage children \& youth in the participative planning process is, in our opinion, a serious professional slip. We do not insist and argue that children and youths in general must be part of the decision process when tourism planning is taking place in a local community. However, it is a professional requirement that these groups, balanced in gender and age, have equal opportunities and are in a position to express their opinions as part of participative planning activities in the field of tourism.

The idea that children \& youth may be the best informants about themselves /5/, /6/ should encourage scholars to conduct empirical research in the field of tourism with rather than about children. Such studies may reveal 
elements of behaviour that adults may not have considered, children's understanding of selfpresentation rules and emotional regulation is limited compared to that of adults and usually develops throughout childhood and adolescence $/ 6 \mathrm{a} /$. Also, children, in general, and young children, in particular, are less socially conditioned with pre-conceived notions. Additionally, such studies may highlight children's attitudes toward tourism as having no voice or option but to follow their parents' decisions. To summarize, influenced by the post-modernist and feminist movement, it is claimed here that exploring childhood experiences based on children's voices, rather than adults' or experts' assumptions is essential in advancing tourism scholarship and industry knowledge and may contribute to developing a more inclusive view of tourism and its impact.

One of the purposes of the parallel research /7/ was to give voice to primary school pupils in four Slovenian primary schools and to explore their views on the tourism environment which surrounds them.

\section{Children \& youth in tourism - literature review}

Unfortunately, there is little or no theoretical and empirical literature that considers the voices of the younger generation in the planning and development of tourism. Little has changed since /8/ Graburn's observation, almost thirty-five years ago, of the absence of children in tourism literature. Research that discusses children as tourists has primarily focused on children's influence on parental decision making /9/, /10/, /11/, /12/ and children's influence on adult tourists' experiences $/ \mathbf{1 3} /, / \mathbf{1 4} /, / \mathbf{1 5} /$. With few exceptions, the studies of children have been from an adult perspective, though some writers have recognised the importance of children as a market segment /16/, /17/, /18/. For instance, /19/ Connell refers to the phenomenon of "toddler tourism", which emerged in the United Kingdom stimulated by the British TV program, Balamory, set on the Isle of Mull in Scotland.
In tourism research, children \& youth have been largely ignored in terms of active decisionmaking or negotiation $/ \mathbf{2 0}$ /, but in the last two decades increasing attention has been paid to the potential of children to act as influences on holiday decision making. /21/Ryan, for example, found that children act as catalysts to visit attractions. /22/ Thornton, Shaw and Williams argued that children possess the ability to make suggestions about holiday choices, but the ultimate decision-making remains with the parents. However, the authors also contended that parents rate children's satisfaction more highly than their own.

It is only in the last two decades that researchers have begun to examine how children experience holidays. /23/ Cullingford in a study of attitudes toward overseas holidays of British 7-11 year old children, found that children had clear ideas of which countries were attractive as holiday destinations. It was the developed world which was most desirable; in other words, that which was culturally familiar. The author found, for most of the children in the study, that travel meant beaches, good weather and eating out rather than cultural sightseeing. He explained that "for the most part, children are confined to their clearly demarcated 'holiday' and while they enjoy the entertainment of a beach holiday with friends, they are also aware of the differences in being abroad" (p.125).

The dramatic influx of visitors to destinations and the reconstruction of destinations to appeal to children highlight the role of the child in today's holidaying family. However, the value of researching children goes beyond the commercial incentive. /24/ Graburn and /25/ Cullingford called for research that enquires more broadly about the perceptions children have of other countries and peoples and the impact childhood experiences have on their later adult holidays.

More than thirty years ago, Graburn /26/ pointed out the importance of studying the impact of tourism on the life-cycle of the 
individual, the formation of "identity and aspirations" and the development of "attitudes toward other peoples and places in the world" (1983, p. 2). He also called upon tourism researchers to begin to study the impact of tourism on children. Studies of the effects of tourism on the historical, natural and geographical awareness of growing children are therefore lacking.

The importance of including the traditionally excluded voices of children and youths in the planning of public spaces is also an issue articulated in the literature. For example, /27/ Parnell and Patsarika's work focuses on children's contributions to the planning of school-related spaces, while /28/ Laughlin and Johnson's deal with youth roles in informing decisions related to housing developments. Very few of the researchers studied how children in destination areas perceive tourists.

According to /29/ Gamradt, tourism affects the lives of children particularly if one or more of their relatives and/or acquaintances are employed in the industry: "[S]uch children will have acquired knowledge of, and may even have formed strong opinions about tourists and the tourism industry" (p. 735). These studies offer a strong foundation on which to understand the life worlds of children within host communities located in tourism destinations. However, except for a few studies /30/ Buzinde and Manuel-Navarrete's exploring Mayan children's perceptions of boundaries caused by tourism enclaves, and /31/ Gamradt's with Jamaican children, analyses of children's perceptions of their surrounding landscapes, particularly those zoned in favour of tourism at the expense of locals, have been under represented.

There are several possible factors that may help explain the deficiency of research on children and tourism:

1. Research with children demands special expertise $/ 32 /$. As far as implementing the research is concerned, interviews and surveys with children must be conducted by researchers who are familiar with specific techniques (e.g., doll-play, storytelling and pictorial questions) and procedures (e.g., the Berkeley Puppet Interview) used for investigating children at various developmental stages.

2. In many countries, scholars who wish to involve children in their studies need permission not only from parents but also from government agencies and ethics committees inside and outside a university.

3. An additional factor that hinders scholars from studying children is the state of the current body of tourism knowledge and unfamiliarity with theories needed to conceptualize children's behaviour. Most lines of thinking in tourism studies are based on the assumption that tourists are free agents who can choose from a wide range of travel options, many of which form an escape from daily routines and social obligations $/ 33 /$.

4. Tourism is also often conceptualized, based on an individual's willingness to learn by being exposed to other cultures and social realities. These paradigmatic assumptions are often not valid in children's travel experiences. Children are frequently obliged to travel as part of a family unit, possibly even against their own will. Likewise, themes such as existential authenticity or performativity may be significantly less applicable to studies of young children, as they may not be able to relate to such issues. Thus, researchers need to be familiar with theories that are essential to contextualize children's behaviour, including behaviours followed out of obedience.

To help bridge these gaps in knowledge, tourism scholars may consider various stages in the research process. First, researchers should consider familiarizing themselves with developmental psychology and, specifically, social developmental theories. /34/ Erikson's psychosocial stages of cognitive development, for example, could help in understanding changes in one's tourist experiences during childhood. /35/ Piaget's developmental stage theory may explain the impact of museum visits 
at varying child development stages. As far as the research method is concerned, scholars should consider children's ages and other demographic differences, including their cultural background and not approach them as a homogenous group.

The development of the child and their understanding of the world around them occurs in constant interaction with the environment. One of the most important interactions is certainly their interaction with parents; parental views on the environment are passed on to their children - through explicit or implicit attitudes. Both attitudes are recognized and adopted in their own way by children in the socialization process /36/. Implicit attitudes are those that are activated automatically and parents are rarely aware that they express them. Implicit attitudes are mainly forms of traditional parenting rooted in family traditions. Parents have difficulty recognizing such in their relations with children. Explicit attitudes are also apparent through parental reflection and analysis in the process of interaction with their child. The attitudes expressed by parents towards tourists are often implicit as they are often unaware of the content of these attitudes which are frequently coloured by prejudices and stereotypes giving them a special significance in the process of interaction with children. In the process of growing up, children are very attentive listeners and they recognize the views of their parents. Although the adoption of parental attitudes is not automatic and also drawn on children's own experiences, parents' attitudes have a strong influence on the development of children's views.

Thus, the parallel research study /37/ explored the perceptions of 11-12 year old children of tourists, hosts and their parents' opinion of tourists, taking into account the stages and development of the tourist destinations and whether the children's parents or relatives were employed in the tourism industry. Children are very careful observers of the attitudes of their parents, though even from an early age it is not always certain whether they will agree with those attitudes. /38/ Ozturk et al. examined how children view their parents' attitude towards smoking and found that they can clearly distinguish between positive and negative attitudes. Exploring how children see the racial attitudes of their parents, /39/ Castelli et al. observed that parents of white children prefer their children to play with whites. This research shows that children very closely monitor the attitudes of their parents.

A traditional theme often explored in terms of the attitudes of the host population to tourists is prejudice. As is well known, prejudices are a phenomenon which occurs relatively early in human development /40/. Prejudices are not just a simple ratio of intolerance towards others who are different; they are very complex categories which depend on an equally complex interaction between socio-contextual and socio-cognitive variables. Therefore, it is necessary that the various dimensions of tourism appearance, shape and development are explored.

\section{Methodology and objectives of the research study}

The parallel research study /41/ was conducted in spring 2015. The perception of tourists was measured in four different Slovenian towns:

- The first was the small town of Trebnje in central Slovenia where tourist activities are very poor and the hospitality industry almost exclusively serves the local population. Those who are employed in tourism and hospitality work off-site, in the nearby capital city of Ljubljana and other cities.

- The second was the small town of Brežice in southeast Slovenia on the edge of which there is a spa. In this town there are almost no tourist activities as the hospitality industry in the town, to a large extent, serves mainly the local population. The nearby spa provides the local inhabitants with tourism job opportunities.

- The third, were two small towns on the Adriatic coast, Lucija and Piran, where 
tourism activity is very intense. In these towns, there is practically no other industry besides tourism activities.

The research related to three municipalities Brežice, Piran (including the settlements of Piran and Lucija within that municipality) and Trebnje. Both Brežice and Trebnje have similar labour force characteristics; in Brežice the selfemployed represent $15.3 \%$ of the workforce and farmers $32.6 \%$ of the workforce. In Trebnje, the self-employed are $14.6 \%$ and farmers $38.4 \%$. In the Piran municipality, the self-employed are $12.7 \%$, but farmers (a significant component of cultural/heritage \& sustainable tourism) are only $6.5 \%$ (RS Statistical Office Workforce data, 2016). However, if we look at tourism data, there is a strong distinction between the three municipalities. On overnight stays, Piran/Pirano received 270,022 (of which $73 \%$ were foreign and $27 \%$ domestic); Brežice received 118,633 (63\% foreign and 37\% domestic) whilst Trebnje received 1,405 (84\% foreign and 16\% domestic), (RS Statistical Office Tourism data, 2016).

Participation in the study was voluntary. Before testing, the researchers received approval from the relevant school administrations and obtained the written agreement of the children's parents to their child's participation in the study.

The study had three objectives:

1. To determine how schoolchildren in the 6th and 7th (age 11-12 years) grades in elementary schools perceive tourists.

2. To ascertain how children perceive the host population, as opposed to tourists.

3. To measure how children see the way their parents perceive tourists.

\section{Results and discussion}

The research results proved very interesting; children from the least-developed tourist area (Trebnje) had a more positive assessment of tourists. Slightly less positive, but still with positive ratings, were the assessments given by children from Brežice, the city in which tourism is not developed but has a large spa outside the town. Children from the most developed Slovenian tourist destinations of Lucija and Piran assessed tourists least positively. The differences in grades were statistically significant when compared by location.

What was very interesting were the differences when analysing individual factors. On the Activity factor, tourists were rated highly, but the range between the highest and lowest score was broad. Children in the town without a significant tourist industry had a rather high assessment of the Activity of tourists, but children in the tourist area with the most intense touristic activity evaluated it as negative or, it might be better to say, as a nonactive. This non-movement of tourists certainly should be interpreted in the context of the nature of destinations. Two active tourist destinations (Piran and Lucija) are coastal destinations for summer vacations on the beaches. Hence, a probable recorded perception of tourists is of them lying on the beach and not moving around much. This perception is obviously also enhanced by what the children hear from their parents, who evaluate the Activity factor of tourists more negatively than children do. On the other hand, children who do not have a specific personal experience with tourists see them as people who are active, fast, mobile and spontaneous, as is usually associated with this factor. As the level of tourist activity in some regions intensifies, children perceive tourists as less active, less fast, less spontaneous and less animated.

At this stage we may introduce the concept that tourism activity may be regarded as either tangible or intangible, and to a degree we must recognise this when measuring the response of children to the tourism environment. Mass tourism - as located in seaside resorts of which Piran and Lucija are prime examples - is very tangible in the physical aspect of buildings (hotels, guest houses and related tourism facilities) as well as in the overwhelming level of impact tourism has on the socio-economic environment. It is also tangible in the 
organisation and deployment of tourists; they will tend to arrive in groups, they will make visits in groups and they will conduct social activities in groups. They are thus a tangible and demonstrable feature. In order to ensure sustainable tourism development and avoid problems of over-tourism, all voices from different stakeholders groups in the local destination need to be heard and respected. In line with that, sustainable tourism development has to include a carrying capacity study; that is, an estimate of "the maximum number of people who can use a site without an unacceptable alteration in the physical environment and without an unacceptable decline in the quality of the experience to both visitors and residents. The factors that need to be considered are physical impact of tourists, ecological impact of tourists, perceptions of overcrowding, and cultural and social impact on local residents. The carrying capacity study is central to meeting the objectives of sustainable tourism development, which is to ensure that the tourists and day visitors attracted to the particular destination will not have a deleterious impact on the cultural or natural sites; that overcrowding will not result in visitor dissatisfaction and that local people will not feel antagonistic towards their "guests". This is essential if tourism is to contribute to the conservation of cultural and natural heritage though the realisation of economic value and raising awareness of, and commitment to, the local patrimony. Sustainable tourism - whether cultural, heritage or environmental - will tend to have a far lower profile. Groups will be of a far lower size, and many sustainable tourists will come as individuals or as couples. Carrying capacity of sustainable and heritage tourism sites also tends to downsize the number of visitor groups. In this sense, sustainable tourism is far less tangible and far less evident. However, we do not as yet have physical evidence (tourism spend per capita) as to the extent to which LST tourists spend less or more than sustainable tourists.

\section{Limitations}

There are two major limitations to this study. The first is cultural; the study was conducted in the Slovenian cultural environment. In this case, while it is only relatively applicable to other European cultures, we can still talk about the possibilities of its application in nonEuropean conditions. Gamradt $/ 42 /$, in his research with children in Jamaica, showed a very positive attitude towards "visitors" to Jamaica. To be able to generalize the results, the study should be repeated in other cultures.

A second limitation is that children in areas where tourism has a low profile (albeit not a necessarily low economic input) may tend to have little relationship with tourists unless their family is directly engaged in some tourism activity (e.g. agro-tourism). Children in areas where tourism has a high level of intensity will have a strong relationship to tourism - albeit positive or negative. This tends to highlight one of the dilemmas of sustainable tourism; it seeks to exploit the fact that sustainable destinations are "off the beaten track" but at the same time tries to promote sustainable destinations to increase inflows and revenues. The tipping point between profitability and sustainability is very difficult to judge and to reach a balance. Whilst sustainable tourism has a low profile, its environmental impact is low but its socio-economic impact from evidential tourism economic inputs is low. If the profile is made greater, the socio-economic impact will increase, but the potential environmental damage may also increase. We may envisage that this an issue affecting children in sustainable tourism areas may they see tourists as an advantage (income, economic development) or a threat (destruction of the environmental, cultural and heritage environment)?

A third limitation is related to the locations where the research was conducted. These are all small towns due to the nature of tourist activities in Slovenia, which mainly relate to small towns. It is quite possible that in a larger city, results would be different; this compels future research to be extended to different cultural environments, as well as to larger cities. 
This survey explored children's attitudes towards tourists at one point in time. Our subjects were children who were 11-12 years of age. In further investigations, it would be competent to see how these concepts change over time as they grow up, such as for example in later adolescence and early adulthood. We would then obtain better answers about relations between the local populations and their visitors.

\section{Findings and conclusions}

What is most important in this study is the fact that we have shown that children \& youth are not only 'residents' in tourist areas, towns and villages, but participants in events in these areas and careful observers of the events around them. However, in spite of all the research done on tourism, no ever asks the children their views about tourism.

This research has shown that children \& youth have very clearly defined attitudes towards tourists coming to the destinations in which they live; but the fact is that no one asks children about their views, although tourists are constantly entering into their living space. The simplified answer, that tourism is an economic activity that allows children an orderly life, is clearly not a sufficient answer. Since children are obviously part of what is called a tourist destination, they also need to be consulted. Otherwise, as seen in this study, children carry negative biases onto the next generation, because prejudice, as it is well known, is transferred inter-generationally.

There is very little or almost no research available in which youth's or children's needs are discussed, particularly in the development of tourism destinations or development of local community tourism activities elsewhere. The next conclusion is more obvious: the definition of destination "a geographic area, territorialadministrative or an important attraction that is trying to offer its visitors experiences which can range from acceptable to unforgettable" /43/. From a conceptual point of view, that is, if we take into consideration the manageability of a destination, it is far more efficient to regard a destination as a geographical region that has necessary critical mass or as a cluster attraction. A destination can be regarded as a combination (or even as a brand) of all products, services and ultimately experiences provided locally /44/. In this definition, it is clear that from the point of view of the hosts these are both adults and children, therefore tourism destinations "have" this age group which can perform and should have input when it comes to planning and development.

Perhaps we may also suggest that a critical theme is to move away from the concept of viewing tourism destinations purely in economic and financial capacity terms. This includes valuing outputs in relation to what are frequently intangible financial markets, or inputs categorised solely in relation to consumer choices. Sustainable tourism, by its ethical basis, attracts those who to a degree reject consumerism and the commoditisation of tourism products. Thus, to engage and incorporate that tourism base, we require to employ parallel concepts which have a strong and vibrant relationship to ethical/sustainable tourism issues. These are developments which are based on the cultural heritage and that seek to protect and preserve often fragile environments (physical, historical and cultural) within the sensitive rural/urban location. This concerns tracking and determining carrying capacity as well as analysing the point at which levels of tourism activity may commit serious damage to that fragile environment. This has a profound impact on children, as it is their future (and the future of their own children) which we are failing to assess and comprehend. In the development of destination management, there is almost no evidence that youths and children are invited and asked about their views on destination development plans. This study showed that the mere presence of tourists is an important socialization factor in the development of children. Children \& youth observe and listen to what their parents say and how they behave towards tourists. They see how their parents treat tourists. Perceptions that they see in their parents and their own experiences with tourists define their 
'social competence'. Many analyses of the workforce employed in hospitality and tourism have shown that young people are reluctant to enter professions in tourism and hospitality. Many authors emphasize that there is a very high turnover of staff in the tourism industry. One result of this research shows that children in tourism-intensive areas are internalizing the relatively negative perception of tourists that their parents have. Therein lays one of the important problem factors with labour that is found in the tourism and hospitality industry. Therefore, it is wrong not to ask children \& youth about their views and not to care about their attitude towards tourists, because these children are the basis for the future development of tourism activities in these areas.

Notes

/1/ Inskeep, E. (1994). National and regional tourism planning. London: Routledge, 8.

/2/ FernWeh, (2002). Tourism Review - Working Group on Tourism \& Development, Rio: Ten years on - Red card for tourism?

/3/ Sancar, F. (2005). Participatory learning and action: Children voices in municipal planning, Department of Planning and Design College of Architecture and Planning University of Colorado, USA, 27-36.

/4/ Koščak, M., Knežević, M., O’Rourke, T., (2017). No one asks the children, right? (Unpublished paper).

/5/ Atzaba-Poria, N., Pike, A., \& Deater-Deckard, K. (2004). Do risk factors for problem behaviour act in a cumulative manner? An examination of ethnic minority and majority children through an ecological perspective. Journal of Child Psychology E Psychiatry, 45(4), 707-718.

/6/ Measelle, J. R., Ablow, J. C., Cowan, P. A., \& Cowan, C. P. (1998). Assessing young children's views of their academic, social and emotional lives: An evaluation of the self-perception scales on the Berkeley puppet interview. Child Development, 69(6), 1556-1576.

/6a/ Banerjee, R., \& Yuill, N. (1999). Children's understanding of self-presentational display rules: Associations with mental-state understanding. British Journal of Development Psychology, 17(1), 111-124.

/7/ Koščak, M., Knežević, M., O’Rourke, T., (2017). No one asks the children, right? (Unpublished paper).
/8/ Graburn, N. (1983). Editor's page. Annals of Tourism Research, 10(1), 3-5.

19/ Filiatrault, P., \& Ritchie, J. R.B. (1980). Joint purchasing decisions: A comparison of influence structure in family and couple decision-making units. Journal of Consumer Research, 7(2),131-140.

/10/ Fodness, D. (1992). The impact of family life cycle on the vacation decision-making process. Journal of Travel Research, 31(2), 8-13.

/11/ Seaton, A. V., \& Tagg, S. (1994 ). How different are Scottish family holidays from English? In A. Seaton (Ed.), Tourism: The state of the art (pp. 540548). Chichester: John Wiley \& Sons.

/12/ Wang, K., Hsieh, A., Yeh, Y., \& Tsai, C. (2004). Who is the decision-maker: The parents or the child in package group tours? Tourism Management, 25(2),183-194.

/13/ Johns, N., \& Gyimothy, S. (2002). Mythologies of a theme park: An icon of modern family life. Journal of Vacation Marketing, 8(4), 320-331.

/14/ Salma, U. (2001). Kids call the shots: How Aussie children affect travel. BTR Tourism Research Report, 3,43-49.

/15/ Thompson, W.N., Pinney, J. K., \& Schibrowsky, J. A. (1996). The family that gambles together: Business and social concerns. Journal of Travel Research, 34(3),70-74.

/16/ Cullingford, C. (1995). Children's attitudes to holidays overseas. Tourism Management, 16(2),121-127.

/17/ Ryan, C. (1992). The child as visitor. World Travel and Tourism Review, 2,135-139.

/18/ Swarbrooke, J., \& Horner, S. (1999). Consumer behaviour in tourism. Oxford: ButterworthHeinemann.

/19/ Connell, J.(2005). Toddlers, tourism and tobermoray: Destination marketing issues and television-induced tourism. Tourism Management, 26(5), 763-776.

/20/ Howard, D., \& Madrigal, R. (1990). Who makes the decision: The parent or the child? The perceived influence of parents and children on the purchase of recreation services. Journal of Leisure Research, 22(3), 244-258.

/21/ Ryan, C. (1992). The child as visitor. World Travel and Tourism Review, 2,135-139.

/22/ Thornton, P.R., Shaw, G., \& Williams, A.M. (1997). Tourist group holiday decision-making and behaviour: The influence of children. Tourism Management, 18(5), 287-297.

/23/ Cullingford, C. (1995). Children's attitudes to holidays overseas. Tourism Management, 16(2),121-127. 
/24/ Graburn, N. (1983). Editor's page. Annals of Tourism Research, 10(1), 3-5.

/25/ Cullingford, C. (1995). Children's attitudes to holidays overseas. Tourism Management, $16(2), 121-127$.

/26/ Graburn, N. (1983). Editor's page. Annals of Tourism Research, 10(1), 3-5.

/27/ Parnell, R., \& Patsarika, M. (2011). Young people's participation in school design: Exploring diversity and power in a UK governmental policy case-study. Children's Geographies, 9(3/4), 457-475.

/28/ Laughlin, D. L., \& Johnson, L. C. (2011). Defining and exploring public space: Perspective of young people from Regent's Park. Children's Geographies, $9(3 / 4), 439-456$.

/29/ Gamradt, J. (1995). Jamaican children's representations of tourism. Annals of Tourism Research, 22(4), 735-762.

/30/ Buzinde, C. N. \& Manuel-Navarrete, D. (2013). The social production of space in tourism enclaves: Mayan children's perceptions of tourism boundaries. Annals of Tourism Research, 43, 482-505.

/31/ Gamradt, J. (1995). Jamaican children's representations of tourism. Annals of Tourism Research, 22(4), 735-762.

/32/ Measelle, J. R., Ablow, J. C., Cowan, P. A., \& Cowan, C. P. (1998). Assessing young children's views of their academic, social and emotional lives: An evaluation of the self-perception scales on the Berkeley puppet interview. Child Development, 69(6), 1556-1576.

/33/ Obrador, P. (2012). The place of the family in tourism research: Domesticity and thick sociality by the pool. Annals of Tourism Research, 39(1), 401420.

/34/ Erikson, E. H. (1993). Childhood and society. New York: W.W. Norton.

/35/ Piaget, J. (1977). The development of thought: Equilibration of cognitive structures. Oxford: Viking.

/36/ Holden, G.W., \& Hawk, C.K. (2003). Metaparenting in the journey of child rearing: A cognitive mechanisms for change. In L. Kuczynski (Ed.), Handbook of dynamics in parentchild relations. Thousand Oaks: Sage Publications INC.
/37/ Koščak, M., Knežević, M., O’Rourke, T., (2017). No one asks the children, right? (Unpublished paper).

/38/ Ozturk, C., Kahraman, S., \& Bektas, M. (2013). Effects of perceived parental attitudes on children's views of smoking. Asian Pacific Journal of Cancer Prevention,14(4), 2615-2624.

139/ Castelli, L., Carraro, L., Tomelleri, S., \& Amari, A. (2007). White children's alignment to the perceived racial attitudes of the parents: Closer to the mother than the father. British Journal of Developmental Psychology, 25(3), 353-357.

/40/ Raabe, T., Beelmann, A. (2011). Development of Ethnic, Racial, and National Prejudice in Childhood and Adolescence: A Multinational Meta-Analysis of Age Differences. Child Development, 82(6),1715-1737.

/41/ Koščak, M., Knežević, M., O’Rourke, T., (2017). No one asks the children, right? (Unpublished paper).

/42/ Gamradt, J. (1995). Jamaican children's representations of tourism. Annals of Tourism Research, 22(4), 735-762.

/43/ Bornhorst, T., Ritchie, J.R.B., \& Sheehan, L. (2010). Determinants of tourism success for DMOs \& destinations: An empirical examination of stakeholders' perspectives. Tourism Management, 31(5), 572-589.

/44/ Buhalis, D. (2000). Marketing the competitive destination of the future. Tourism Management, 21(1), 97-116.

\section{Literature}

1. Knickerbocker, H., Altarríba, J. (2013). Differential repetition blindness with emotion and emotion-laden word types. Visual Cognition, 21(5):599-627

2. Republic of Slovenia Statistical Office (August 2016). Workforce data. On line:

http://www.stat.si/StatWeb/. [Accessed: 27 January 2017]

3. Republic of Slovenia Statistical Office (August 2016). Tourism data. On line:

http://www.stat.si/StatWeb/. [Accessed: 27 January 2017] 